\title{
Pendidikan Islam Rahmat li al-'Alamin dan Implikasinya terhadap Karakter (Studi Pesantren Metal Mulim al-Hidayah Pasuruan)
}

\author{
Aditia Muhammad Noor \\ Universitas Brawijaya \\ Email:maditia608@gmail.com \\ Received: April 3, 2021 | Accepted: June 21, 2021
}

\begin{abstract}
The "Metal" Islamic boarding school was established with a very humanistic purpose. While some educational institutions only accommodate students excelers, superior, smart and have character. The "Metal" person boarding school is present as a place that accommodates students with various social backgrounds, ranging from druging addicts, homeless people, free sex victims, until toddlers who deliberately abandoned their parents. Seeing the arrogance and inequality of education while this time, making the "Metal" person boarding school take a very meaningful role for them to be formed into people who have character. Because education is the right of all humans without having to look at the status of his past. Rahmatan li al-'alamin Islamic education in the "Metal" person boarding school have an impact on the character of students who are able to make them as perfect people.
\end{abstract}

\begin{abstract}
Abstrak
Pondok pesantren "Metal" didirikan dengan tujuan yang sangat humanis. Disaat sebagian lembaga pendidikan hanya menampung peserta didik yang berprestasi, unggul, cerdas dan berkarakter. Pesatren "Metal" hadir sebagai wadah yang menampung peserta didik dengan berbagai latar belakang sosialnya, mulai dari pecandu narkoba, gelandangan, korban seks bebas, hingga balita yang sengaja ditinggalkan orang tuanya. Melihat ketimpangan pendidikan selama ini, membuat pesantren "Metal" mengambil peran yang sangat berarti bagi mereka untuk dibentuk menjadi insan yang berkarakter. Sebab pendidikan merupakan hak semua manusia tanpa harus memandang status masa lalunya. Pendidikan Islam rahmatan li al-'alamin pada akhirya mampu memberikan dampak dalam membentuk karakter santri dan memiliki kepribadian yang unggul sehingga harkat dan martabatnya sebagai serang manusia dapat terangkat.
\end{abstract}




\section{Keywords \\ Model of fducation, Islam rahmat li al-'alamin}

\section{Pendahuluan}

Pada umumnya pesantren digolongkan sebagai lembaga yang dinilai aktif dalam pembentuk moralitas yang tanpa sedikitpun membedakan latar belakang peserta didik (santri) untuk diarahkan. Namun perubahan yang dikehendaki sering kali terjadi disintegrasi dalam tataran praktiknya. Pesantren pada umumnya hanya menampung santri yang cenderung normal yang tidak pernah tersangkut kasus sosial seperti pemakai dan pengedar narkoba, pelaku seks bebas dan anak jalanan, yang semestinya mereka pun berhak memasuki dinamika pendidikan pesantren untuk dibentuk moralitasnya, diberikan kasih sayang dan diangkat martabatnya sebagai seorang manusia.

Hal ini memungkinkan jika pesantren menampung santri mantan pecandu narkoba, korban seks bebas dan anak jalanan akan mempengaruhi pola perilaku santri lain, sehingga kenakalan-kenakalan akan menyebar luas. Disisi lain muncul perasaan minder dari pecandu narkoba, korban seks bebas dan anak jalanan untuk bergabung dengan yang lain karena merasa kotor, kurang berakhlak dan terlalu banyak kasus telah dideritanya. Apalagi jika terjadi di sekolah-sekolah apada umumnya, keberadaan mereka akan mempengaruhi grade sekolah dan mematikan citra sekolah.

Konsekuensi dari keterbatasannya penampungan pesantren untuk santri khusus tanpa cacat sosial, pada akhirnya pendidikan mengalami disorientasi yang hanya akan dinikmati bagi segelintir orang. Padahal berdasarkan pasal 3 Undang-undang No. 20 tahun 2003 tentang Sistem Pendidikan Nasional menyebutkan: "Pendidikan nasional berfungsi mengembangkan kemampuan dan membentuk watak serta peradaban bangsa yang bermartabat dalam rangka mencerdaskan kehidupan bangsa, bertujuan untuk berkembangnya potensi peserta didik agar menjadi manusia yang beriman dan bertakwa kepada Tuhan Yang Maha Esa, berakhlak mulia, sehat, berilmu, cakap, kreatif, mandiri, dan menjadi warga negara yang demokratis serta bertanggung jawab"

Lantas apakah pesantren dikatakan sebagai lembaga pendidikan nasional?, jelas hal ini termaktub dalam UU No. 22 tahun 1989 yang juga memiliki peran sebagai lembaga pendidikan nasional. Artinya bahwa pesantren memiliki tanggungjawab moral dalam membantu peserta didik mendapatkan haknya untuk di didik dan diarahkan agar terbentuk akahlak mulia dan terangkat martabatnya.

Dilihat dari tataran teori, Dawam Rahaharja menyebutkan peran pesantren tidak sebatas institusi religi semata (Mahmud Yunus, 1990; Wahid, 2001), akan tetapi juga bagian dari institusi sosial (Raharjo, 1985). 
Maka peran pesantren bukan hanya menangani masalah keagamaan semata, melainkan juga turut andil dalam pemecahan masalah sosial (Qomar, 2005). Tugas sosial ini tentunya tidak akan mengurangi tugas utama keagamaan, sebab dengan turut andil pesantren memberikan sumbangsih penyebaran nilai dan kemaslahatan bagi masyarakat secara luas akan menumbuhkan kepercayaan khalayak terhadap pesantren. Melalui peran pesantren dalam dimensi sosial diharapkan mempu mengentaskan problematika sosial (Pohl, 2006) agar tercipta tata kehidupan yang sehat dan harmonis.

Dari keresahan dan minimnya pesantren yang menanggulangi permasalahan sosial, Pesantren "Metal" lahir sebagai problem solving yang hadir menumpas segala bentuk ketimpangan yang juga bersifat kuratif dalam menanggulangi masalah sosial seperti pengguna narkoba, pelaku seks bebas hingga anak-anak jalanan yang di didik dengan penuh kasih sayang. Di dirikan pada tahun 1992 yang juga dikenal sebagai tempat rehabilitas untuk membentuk karakter yang lebih baik.

Sebagai lembaga pendidikan serta tempat rehabilitas, pesantren "Metal" memiliki pola pendidikan yang khas yakni pendidikan berbasis rahmatan li al-'alamin atau pendidikan "kasih sayang". Pesantren ini memiliki cara yang unik dalam menerapkan pendidikanya bagi mereka, yakni dengan ketulusan dan kasih sayang yang selalu terpancar disetiap kehidupan santri. Hal ini diciptakan agar para santri merasakan perhatian, mendapatkan kasih sayang dan cinta, dimana selama ini mereka tidak pernah merasakan hal itu sebelumnya. Selain itu dampak dari pedidikan kasih sayang ini terasa sangat signifikan bagi para remaja untuk lebih mendorong mereka ke arah yang lebih positif (Arar, Orucu and Kucukcayir, 2018).

Keberadaan pesantren yang berlokasi di Desa Rejoso Pasuruan menjadi salah satu problem solving atas beberapa kasus yang kerap terjadi di Pasuruan. Berdasarkan data Badan Pusat Statistika (BPS) dari tahun 20142016 tercata untuk kasus penyalah gunaan narkoba sebanayak 73 kasus, perkosaan sebanyak 8 kasus, pencabulan 28 kasus, pembunuhan 19 kasus dan 72 kejahatan umum. Selain itu berdasarkan rekapan Satuan Reserse Narkoba (Satreskoba) Pasuruan mencatat 75 kasus penyalah gunaan narkoba sepanjang tahun 2019, angka ini terjadi peningkatan sedikit dari tahun 2018 yang tercatat 70 kasus narkoba.

Dari kasus diatas menunjukan bahwa tingkat kejahatan di daerah Pasuruan cukup memperihatinkan dan yang lebih parah lagi rentetan kasus tersebut banyak dilakukan kaum remaja. Hal ini diakibatkan karena kurangnaya pengawasan, perhatian orang tua dan salahnya pergaulan. Hal ini menjadi kekhawatiran tersendiri pada kaum remaja yang sangat sulit sekali untuk diarahkan kearah yang lebih baik. Salah satu upaya kuratif 
dalam hal ini dengan mengedepankan aspek pembentukan akhlak yang baik menjadi prioritas utama dalam menanggulangi kasus tersebut.

Tentunya pembenahan moral perlu mendapatkan perhatian lebih yang tidak hanya menjadi tugas lembaga sosial semata, melainkan tanggung jawab bersama dari semua elemen baik masyarakat, keluarga, sekolah termasuk pesantren sebagai patron pemahaan agama dan pembentukan moral.

Karenanya, seiring dengan kontribusi pesantren dilingkungan sosial dan atas respon degradasi moral yang terjadi di Pasuruan maka lembaga ini berinisiatif unutk menampung santri pecandu narkoba, korban seks bebas dan anak jalanan. Menurut Bu Nyai Lutfiyah selaku pimpinan pesantren mengatakan terdapat beberapa faktor yang dialami mereka. "Pertama, kurangnya kasih sayang dan perhatian. Faktor ini adalah masalah yang banyak dialami oleh sebagian besar para santri, bisa karena orang tua yang terlalu sibuk karena urusan kerja, atau orang tua yang telah berpisah dan anak menjadi korban kurangnya kasih sayang. Kedua, minimnya pemahaman agama. Faktor ini terjadi pada keluarga yang juga minim akan pemahaman agama, padahal isi dari ajaran agama adalah tentang nilai, etika dan norma yang berlaku di masyarakat. Ketiga, salah pergaulan. Lingkungan dan pertamanan juga turut mempengaruhi timbulnya kenalakan-kenakalan remaja, di sisi lain juga kurangnya pengawasan orang tua terhadap anaknya. ${ }^{1}$

Untuk itulah pendidikan Islam rahmatan li al-'alamin (kasih sayang) yang diimplementasikan di pesantren "Metal" menjadi amat penting di dunia pendidikan juga didunia parenting. Hal ini dimaksudkan untuk memberikan perhatian penuh bagi anak-anaknya agar mereka tidak terjerumus dalam keruskaan moral bahkan sebaliknya pendidikan rahamatan lil alamin memiliki orientasi dalam membentuk akhlak yang mulia.

Hal yang paling menarik dari pesantren ini bukan hanya dihuni oleh para santri yang memiliki latar belakang yang kurang baik, melainkan karena pengaruh seorang kiyai yang dapat meluluhkan seekor macan untuk dipelihara dan dijadikan sebagai pengawalnya. Dari kehebatannya itu para pereman tertarik untuk belajar langsung dari seorang kiyai. Lambat laun santri mulai bertambah dengan banyaknya latar belakang permasalahan yang mereka hadapi, mulai dari korban seks bebas, pecandu narkoba hingga orang gila.

Hal yang paling menonjol dan sangat membedakan dipesantren ini, bukan hanya dihuni oleh sekelompok pemuda mantan pecandu narkoba dan pelaku kejahatan lainnya, namun juga ditempati anak-anak hingga orang gila. Mereka hidup berdampingan, saling menghormati tanpa membedakan

\footnotetext{
${ }^{1} \mathrm{Hj}$. Lutfiyah, wawancara (Pasuruan, 10 Februari 2020)
} 
satu dengan lainnya, karena mereka sadar bahwa siapapun yang berada di lembaga itu mereka adalah orang yang butuh akan kasih sayang dan ingin merubah hidupnya menjadi lebih baik.

Hampir dari setiap santri mengutarakan alasan yang sama mengapa mereka memilih pesantren ini sebagai tempat bernaung, yakni pesantren lain hanya menerima santri tanpa masalah sosial, perhatian pimpinan pesantren dengan penuh rasa kasih sayang, tidak ada kekangan dan bebas megekspresikan diri untuk berubah. Maka tidka heran seagian santri memiliki rambut gondrong dan masih merokok diarea pesantren.

Untuk itu, sangat menarik pesantren ini menjadi kajian dalam penelitian, dimana pesantren dengan ciri khas kasih sayangnya mampu merubah karakter santri menjadi lebih baik dan bermartabat. Hal ini sebagaimana Nabi Muhammad memberikan kasih sayang kepada umatnya agar menjadi umat yang baik, berakhlakul krimah dan memilki sifat penyayang kepda sesama. Pendidikan yang diajarkan oleh nabi adalah pendidikan rahmatan li al-'alamin dimana semua makhluk mendapatkan rahmatnya untuk kemudian terbentuk menjadi muslim yang berakhlak dan berbudi luhur.

Sehubungan dengan pendidikan itu sendiri, banyak para tokoh yang mendefinisikannya secara variatif. Menurut (Muhajir, 1993) bahwa pendidikan adalah proses pengebangan subyek didik. Definisi ini mengafirmasi bahwa pendidikan bukan saja dimaknai sebagai transfer of knowledge, namun lebih mengantarkan pada kemandirian hidup, dan kemuliaan akhlak yang mampu merubah cara pandang serta sikap yang lebih dewasa.

Hal ini juga diperkuat oleh asumsi al-Ghazali yang mengatakan bahwa pendidikan bagian proses melahirkan perubahan-perubahan positif baik cara pandang, perubahan mental, aksi dan tingkah laku manusia (Madjidi, 1997). Ghazali lebih menekankan istilah "perubahan" dalam konteks pendidikan dengan memiliki akal sehat, mental yang kuat dan bersikap sesuai dengan norma etika yang berlaku. Orientasi dari hampir semua pakar, memandang pendidikan sebagai wadah membentuk akhlak yang baik, bukan hanya sebatas kecerdasan intelektual.

Pendidikan Islam rahmatan li al-'alamin adalah upaya pendidikan yang bermuara pada pembentukan akhlak peserta didik. Hal ini berdasar pada kandungan surat al-Anbiya ayat 107.

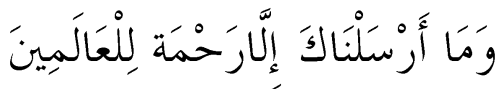

"Aku tidak mengutus kamu (Muhammad), Kecuali untuk jadi rahmat bagi seluruh alam" (Q.S. Al-Anbiya,: 107)

Diantara rahmat Allah kepada manusia adalah dengan hadirnya Muhammad SAW yang bukan hanya sebagai seroang nabi, melainkan juga rasul yang memebawa rahmat agar dapat dinikmati bagi seluruh umat 
manusia, hewan dan tumbuhan di alam semesta tanpa harus membedabedakan suku, agama, budaya bahkan keturuan sekalipun. Rahmat nabi yang mampu kita teladani adalah akhlak yang sempurna, akhlakul alkarimah.

Istilah rahmat dalam konteks pendidikan dimaknasi sebagai kasih sayang yang diberikan kepada umatnya, seperti halnya kasih sayang seorang guru muridnya.

Istilah rahmah menurut Keren Amstrong dalam bukunya Twelve Steps to A Compassionate Life secara termonologi mengatakan bahwa rahim merupakan perlambangan kasih seorang ibu pada anaknya. Hubungan erat antara ibu dan anak memberikan perasaan tulus dalam merawat, mendedikasikan waktu dalam menjaga dan membentuk kepribadian anaknya. Maka dibutuhkan kekuatan, kesabaran dan ketabahan yang tinggi untuk dapat melaluinya dengan baik sebab pada dasarnya manusia adalah makhluk yang selalu bergantung dan membutuhkan kasih sayang (Amstrong, 2010).

Kehadiran Muhammad telah banyak mempengaruhi dalam menyelamatkan manusia menuju jalan keselamatan. Hidupnya adalah bagian kampanye tanpa lelah untuk melawan ketamakan, kezaliman dan untuk menegakan keadilan serta perdamaian. Tidak heran George Bernard Shaw menyebutnya sebagai Savior of Humanity (penyelamat kemanusiaan) (Amstrong, 2007). Dalam pandangan Michel H. Hart disebutkan bahwa Nabi Muhammad adalah satu-satunya manusia yang berhasil dalam kesuksesan, dari berbagai sudut pandangan, baik secara duniawi maupun ukhrawi, bahkan pengaruhnya hingga kini masih terasa, dalam dan mengakar (Amstrong, 2007). Dari kesederhanaan Muhammad juga sebagai sosok yang lahir yatim piatu yang mampu menguasi bidang politik dan menggenggam peradaban menjadi sumber pencerahan dunia. Tidak ada pemimpin revolusioner di dunia ini yang dicintai dan setiap ajaranya selalu ditaati kecuali Muhammad (Hidayat, 2006).

Sedangkan kata 'alam memiliki konotasi makna yang universal, yakni 'alam yang dimaksud dalam ayat tersebut bukan hanya di bagi manusia saja, melinkan semua makhluk dia alam semesta. Jika interpretasi ayat diatas dikontekstualisasikan dalam ranah pendidikan, maka rahmatan li al'alamin adalah konsep dasar pendidikan kasih sayang yang tidak hanya diperuntuka bagi segelintir orang saja, melainkan semua orang. Tidak ada batasan dan peruntukan bagi siapapun dalam pendidikan, terlebih bahwa tujuan pendidikan adalah cara dalam memanusiakan manusia. Pendidikan rahmatan li al-'alamin adalah upaya pembentukan manusia agar mampu menyerahkan diri sepenuhnya kepada Allah sebagai hakikat penghambaan seorang.

Secara eksplisit Islam rahmatan li al-'alamin mengandung arti yang sangat universal meliputi kehidupan semesta alam, tanpa ruang dan waktu. 
Tentunya hal ini juga tidak terlepas dari kehadiran Nabi Muhammad sebagai pembawa rahmat untuk alam semsta ini (Umar, 2000). Maka bisa dikatakan bahwa pendidikan Islam rahmatan li al-'alamin merupakan proses pembentukan peserta didik agar menjadi manusia yang bertakwa kepada Allah berbudi luhur, berakhlak mulia dan bertujuan untuk mengangkat harkat dan martabat manusia. Pendidikan Islam rahmatan li al-'alamin juga mencakup etika, budi pekerti, dan moral sebagai perwujudan dari pendidikan agama.

Kemudian dalam impelemtasinya pendidikan islam berbasis rahmatan li al-'alamin pun bergantung pada bagaimana seorang guru memberikan kenyamana dan kasih sayang yang tulus terhadap peserta didik. Hal ini juga wujud nyata dalam suasana kehidupan di pesantren "Metal", dimana peran seorang guru menjadi titik sentral dalam menjalin hubungan emosional dan hubungan komunikasi efektif (McInerney, 2005) ${ }^{2}$ dengan santri. Peran pimpinan pesantren sangat penting dalam menciptakan nuansa yang lebih harmonis.

\section{Metode}

Penelitian ini menggunakan pendekatan kualitatif deskriptif. Dengan menggunakan metode observasi, wawancara dan dokumentasi. Pondok Pesantren Metal Muslim Al-Hidayah Pasuruan yang beralamatkan di Desa Rejoso Lor Pasuruan Jawa Timur. Alasan peneliti melakukan penelitian disana adalah pondok pesantren merupakan tempat pembinaan sekaligus pusat rehabilitas santriwan-santriwati yang pernah melakukan kejahatankejahatan sosial, pecandu narkoba, dan juga korban seksual. Peneliti beranggapan bahwa objek tersebut sangatlah pas dalam menerapkan pendidikan Islam berbasis rahmatan lil 'alamin. Sedangkan analisinya menggunakan analisis deskriptif. Adapun informan yang kami teliti ialah pimpinan pesantren, ustadz-ustadzah, santri dan alumni.

\footnotetext{
2 Senada dengan hasil ketetapan dari Australian Teaching Council yang mengatakan bahwa guru harus memilki lima kompetensi dasar. (1) mampu menggunakan dan mengembangkan pengetahuan profesional dan nilai-nilai, (2) mampu berkomunikasi, berinteraksi, dan bekerja bersama siswa maupun warga sekolah lain, (3) mampu merencanakan dan mengelola proses pengajaran dan pembelajaran, (4) mampu memantau dan mengukur kemajuan siswa dan hasil pembelajaran, serta (5) mampu merefleksikan, mengevaluasi, dan merencanakan pengembangan berkesinambungan sebagai guru. Dengan demikian, kemampuan menjalin interaksi, berkomunikasi dengan penuh kasih sayang dan kelembutan dari segi keguruan merupakan salah satu kompetensi yang dipersyaratkan.
} 


\section{Hasil Penelitian dan Pembahasan}

Setelah peneliti melakukan analisis data, baik berupa observasi, wawancara maupun dokumentasi. Maka peneliti akan mengintegrasikan antara data yang didapat dengan teori yang sudah ada sehingga tercipta pandangan baru mengenai model pendidikan Islam rahmatan li al-'alamin dan implikasinya terhadap pembentukan karakter di pesantren "Metal". Sebagai upaya mewujudkan tujuan pendidikan, konsep serta implementasi pendidikan Islam di pesantren "Metal" lahir sebagai sebuah solusi yang solutif disaat pendidikan telah kehilangan ruhnya dalam prinsip keadilan, persamaan dan kesetaraan dalam memanusiakan manusia, maka tujuan substantial yang diterapkan dilembaga pendidikan pesantren "Metal" ialah mengembalikan fitrah sebagai seorang manusia dengan pribadi yang berakhlakul karimah, memahami ketauhidan, pengamalan ibadah sampai terciptanya jiwa-jiwa qurani oleh seluruh santri.

Konsep Pendidikan Islam Rahmatan Li Al-'Alamin di Pondok Pesantren "Metal" Muslim Al-Hidayah

Konsep pendidikan Islam pada hakikatnya merupakan tahapan dari prinsip-prinsip hidup ajaran tentang bagaimana manusia menjalankan kehidupannya agar dapat memahami nilai-nilai yang terkandung dalam Islam. Seperangkat proses ini merupakan satu kesatuan utuh yang tidak dapat dipisahkan satu dengan yang lainnya. Sehingga bisa dikatakan bahwa proses pendidikan Islam menjadi pedoman bagi umat manusia agar dapat mencapai keselamatan serta kebahagiaan dalam setiap tingkah lakunya yang sesuai dengan ajaran Islam.

Konsep pendidikan Islam rahmatan li al-'alamin yang diaktualisasikan di pesantren "Metal" yakni berbasis kasih sayang, lemah lembut, komunikasi dan rewards (penghargaan). Konsep ini sama sekali tidak pernah dijadikans sebagai konsep mutlak yang diatur dalam sebuah kurikulum, melainkan konsep ini lahir berdasarkan kebutuhan dan situasi yang mengharuskan konsep tersebut menjadi acuan non formal. Akan tetapi meskipun demikian, konsep diatas berdampak pada berubahnya sikap santri secara totalitas. Hal ini dapat dilihat sejauh mana mereka selama ini kurang mendapatkan rasa kasih sayang, cinta dan kasih dari orang-orang terdekat.

Pondok Pesantren "Metal" Muslim Al-Hidayah berangkat dari minimya pengetauan agama dalam akidah, akhlakul karimah serta minimnya bimbingan dalam melaksanakan ibadah, maka upaya pesantren Pesantren "Metal" Muslim Al-Hidayah sebagai lembaga pendidikan yang berperan khusus untuk membina mereka melalui misi membentuk insan yang bertakwa kepada Allah, berakhlakul karimah serta mengamalkan ibadah diharapkan tiga misi utama tersebut membentuk insan yang 
paripurna, serta dapat menjadi bagian dari masyarakat sebagaimana orang normal para umumnya. Sehingga proses pendidikan Islam dialamya merupakan implementasi pendidikan Islam rahmatan li al-'alamin yang memegang erat teguh nilai humanis agar terangkat harkat dan martabatnya sebagai seorang manusia.

Implementasi Pendidikan Islam Rahmatan Li Al-'Alamin di Pondok Pesantren "Metal” Muslim Al-Hidayah

Implementasi pendidikan yang dibangun di pesantren "Metal" berbeda dengan pola pendidikan pesantren pada umumnya. Jika kita bandingkan pesantren pada umumnya lebih mengedepankan sikap spiritual, intlektual dan selalu mengikuti perkembangan jaman. Sedangkan pesantren "Metal" hanya mengedepankan tiga aspek pendidikan Islam rahmatan li al-'alamin, yakni: akidah, akhlak, dan ibadah.

\section{Penguatan Akidah}

Pengenalan diri dalam pengakuan Sang Khalik sebagai Tuhan merupakan dasar utama dalam pendidikan Islam. Dengan mengakui Allah sebagai pencipta, maka manusia akan mempertimbangkan segala langkah sesuai dengan apa yang diperintah-Nya dan menjauhi segala larangan-Nya. Sehingga penanaman akidah dalam proses pembelajaran di Pondok Pesantren "Metal" Al-Hidayan para santri akan merasa terawasi dan tidak akan terdorong dengan hasrat nafsu diluar larangan-Nya. Di lembaga pendidikan Islam pesantren "Metal" upaya dalam meningkatkan pemahaman tauhid diperlihatkan melalui kegiatan pembacaan Asmaul Husna, hafalan Aqo'idul Iman. Hal ini diharapkan agar peserta didik mengetahui lebih dalam mengenai nama-nama Allah, sifat wajib, mustahil dan jaiz bagi Allah dan rasul-Nya juga sebagai upaya untuk mendekatkan diri kepada Tuhannya, mampu menjadikan pedoman dalam kehidupannya. Penanaman akidah di pesantren "Metal" bertujuan agar santri dapat memperkuat keimanan dan ketaqwaannya sehingga dapat menuntun dirinya kejalan yang diridhoi Allah.

\section{Penanaman Etika (Akhlak)}

Tujuan pendidikan sejatinya mampu merubah pribadi seseorang menjadi lebih baik, bertutur kata yang santun serta dapat mematuhi nilai dan norma-norma yang berlaku. Lembaga pendidikan Islam pesantren "Metal" merupakan wadah bagi para peserta didik untuk dapat dibina dan di didik agar dapat mewujudkan cita-cita pendidikan itu sendiri, yakni memanusiakan manusia. Di lembaga ini penerapkan pola pendidikan Islam lebih mengutamakan karatker peserta didik melalui kegiatan-kegiatan seperti, mencium tangan guru-gurunya serta mengucapkan salam disaat 
bertemu, penyediaan lahan untuk berkebun para santri, memasak sesuai jadwalnya, hingga peran pimpinan pun yang menjadi ujung tombak citacita pesantren. Kedekatan seorang pimpinan ataupun pengasuh adalah alasan mengapa seluruh santri menjadi pribadi yang baik, sebagian besar dari mereka adalah orang-orang yang sangat kurang sekali kasih sayang dari orang tua bahkan ada pula yang tidak mengenal siapa orang tuanya, maka kehadiran pengasuh menjadi pengganti orang tua bagi mereka. Tidak hanya sebagai seorang pengajar sorang pesangsuh atau pimpinan pun menjadi ayah dan ibu mereka selama di pesantren.

Pola pesantren dalam menanamkan nilai-nilai akhlak pada peserta didik sangatlah sederhana tetapi nilai-nilai seperti inilah yang mereka butuhkan untuk dapat berlaku baik kepada siapapun, memiliki tanggung jawab sosial serta membiasakan diri untuk hidup ditengah-tengah norma yang berlaku.

\section{Pembiasaan Ibadah}

Nilai Ibadah yang diterapkan dipesatren "Metal" terlihat dalam kegitan sholat berjamaah, membaca al-quran dan berdzikir seusai melaksanakan sholat. hal ini dirasa sangat penting dalam menanamkan nilai-nilai ibadah. Melalui kegiatan ini peserta didik dapat mengontrol hawa nafsu mereka untuk tidak melakukan perbuatan dosan dan maksiat. Dengan ibadah pula peserta didik dapat menjadikannya sebagai media pertaubatan, berserah diri kepada Tuhannya dan memohon ampunan atas segala dosa yang dilakukannya. Sehingga kegiatan ibadah yang dilaksanakan tercermin dalam bentuk suasana keagamaan yang ada dipesantren "Metal".

Bahkan jika pola pendidikan Islam yang dibangun di pesantren "Metal" tidak terlepas dari pengembangan jati diri dan pembenahan akhlak. Alasan mengapa pendidikan akhlak yang diutamakan ialah agar mereka dapat kembali menjadi pribadi yang baik, memiliki sopan santun, beretika dan memiliki tanggung jawab sosial.

Selain itu tersimpan Beberapa faktor pendukung dalam proses pendidikan Islam Pondok Pesantren "Metal" Muslim Al-Hidayah diantaranya: (1) Niat untuk merubah diri menjadi lebih baik, hal ini sangat mendukung proses pendidikan Islam di Pondok Pesantren "Metal" Muslim Al-Hidayah menjadi lebih cepat; dan (2) Motivasi dan dorongan kuat dari orang tua santri bagian dari pendukung berjalannya proses pendidikan Islam di Pondok Pesantren "Metal" Muslim Al-Hidayah.

Dalam proses pendidikan Islam faktor penghambat tentunya harus menjadi perhatian utama agar pembinaan di pondok Pondok Pesantren "Metal" Muslim Al-Hidayah berjalan lancar. Diantara faktor pengahmbat ialah; 1) Minimnya pengajar baik dari ustadz maupun ustadzah, hal ini sangat memeperhambat proses pendidikan dan pembinaan; 2) Sarana 
penunjang ibadah seperti gedung, masjid serta peralatan ibadah yang kurang memadai hingga kelas yang dialihfungsikan menjadi kamar; 3) Minimnya penggunaan media pembelajaran disaat kegiatan belajar mengajar berlangsung, sehingga materi yang disampaikan para pengajar kurang terkesan kurang efektif dan sangat monoton. Faktor pengahmbat inilah yang menjadikan proses pendidikan para santri-santriwati menjadi kurang efektif.

Dengan adanya faktor pendukung dan penghambat yang ditemukan peneliti di pondok pesantren "Metal" Muslim Al-Hidayah tentunya menjadi bahan perhatian agar faktor pendukung di perkuat dan faktor penghambat yang harus dimaksimalkan. Sehingga proses pendidikan Islam dalam membina para santri yang memiliki masalah sosial dapat berjalan lancar dan efektif.

\section{Implikasi dalam Pembentukan Karakter}

Dari sekian tahan yang dilalui dalam proses pendidikan Islam rahmatan li al-'alamin di Pesantren "Metal" menunjukan bahwa tujuan dari kegiatan pembelajaran adalah membentuk pribadi yang berakhlakuk karimah. Sebab pada dasarnya Pendidikan Islam rahmatan li al-'alamin bukan hanya sebatas corak pendidikan yang mengedepankan rasa toleransi melainkan tentang bagaimana pendidikan dapat ditempuh oleh siapa saja tanpa memendang status sosial untuk diberikan hak yang sama. Pendidikan Islam rahmatan li al-'alamin di pesantren "Metal" berupaya untuk mengangkat martabat para santri yang semula memiliki masalah sosial dan kriminal, maka pesantren ini hadir sebagai bentuk kasih sayang agar mereka mampu beradaptasi ditengah masyarakat.

Implikasi yang dari pendidikan Islam rahmatan li al-'alamin menyentuh pada aspek moralitas dan nilai sosial yang berdampak pada prilaku santri itu sendiri, seperti tutur kata yang sopan, berpaiakain rapih, baik terhadap sesama, menjunjung tinggi nilai sosial; yang dapat kita saksikan dalam kegiatan gotong royong, berkebun, dan berwira usaha. Segala bentuk pendidikan di pesantren "Metal" mengarahkan para santri semata-mata untuk mengembalikan citra yang baik dihadapan sosial dan memanusiakan manusia.

\section{Kesimpulan}

Konsep pendidikan Islam rahmatan li al-'alamin di pesantren "Metal" mengacu pada nilai kasih sayang, lemah lembut, komunikasi dan penghargaan. Aspek-aspek diatas merupakan wujud pendidikan yang sesungguhnya dimana selama ini mereka tidak pernah mendapatkan hakhak itu dalam kehidupannya. Untuk itulah konsep ini menjadi sangat ideal untuk diaktualisasikan dalam konteks pesantren "Metal". 
Implementasi pendidikan Islam rahmatan li al-'alamin di pesantren "Metal" adalah penerapan pendidikan yang humanis, egaliter dan menjunjung tinggi nilai moralitas yang akan menumbuhkan sikap dan kepribadian santri "Metal" menjadi lebih baik. Maka tujuan cita-cita pendidikan Islam rahmatan li al-'alamin akan terwujud apabila penguatan akidah, penanaman etika dan pembiasaan ibadah dapat dilakukan secara kontinuitas. Karena ketiga aspek tersebut akan berdampak pada pembentukan karakter santri. Implikasi pendidikan Islam rahmatan li al'alamin di Pesantren "Metal" terlihat secara jelas dalam keseharian santri menjadi lebih baik. Hal ini tidak terlepas dari konsep yang sudah dilaksanakan serta implementasi pendidikan yang berdampak baik pada pembentukan karakter. Penampilan, tutur kata dan sikap lemah lebuh adalah pengejawantahan dari model pendidikan Islam rahmatan li al'alamin yang hadir ditengah-tengah pesantren "Metal".

Dari sini dapat kita simpulkan bahwa pesantren "Metal" dengan konsep pendidikan Islam rahmatan li al-alamin berbasis kasih sayang memberikan dampak yang dalam membentuk karakter yang sesuai dengan nilai dan norma yang berlaku. Artinya, konsep pendidikan Islam rahmatan li al-'alamin tidak selalu bermuara pada toleransi antar umat beragama, akan tetapi dapat kita maknai sebagai konsep toleransi dalam memberikan pendidikan tanpa membedakan santri yang bermasalah ataupun tidak. Konsep pendidikan Islam rahmatan li al-'alamin berbasis kasih sayang dapat memberikan keadilan yang egaliter, demokratis dan berkeadilan. Dari keunikan itulah pesantren ini memiliki tipologi yang berbeda dengan pesantren pada umumnya yakni, "pesantren rehabilitasi berbasis prilaku" dengan ciri khas latar belakang santri yang variatif dengan model pendidikan Islam rahmatan li al-'alamin yang berimplikasi pada nilai dan karakter santri. Sehingga hal ini akan mudah untuk membedakan ciri pesantren kholaf dan salaf.

\section{DAFTAR PUSTAKA}

Amstrong, K. (2007) Muhammad: Prophet for Our Time. Bandung: PT. Mizan.

Amstrong, K. (2010) Twelve Steps to A Compassionate Life. United States: Alfred A. Knopf.

Arar, K., Orucu, D. and Kucukcayir, G. A. K. (2018) 'These students need love and affection: Experience of a female school leader with the challenges of Syrian refugee education', Leading and Managing, 24(2), p. 28. 
Hidayat, K. (2006) Psikoogi Beragama. JaKarta: Penerbit Hikmah.

Madjidi, B. (1997) Konsep Pendidikan Para Filsuf Muslim. Yogyakarta: alAmin Press.

Mahmud Yunus (1990) Sejarah Pendidikan Islam di Indonesia. Jakarta: Hidakarya.

McInerney, D. M. (2005) 'Educational Psychology - Theory, Research, and Teaching: A 25-Year Retrospective', Educational Psychology. doi: 10.1080/01443410500344670.

Muhajir, N. (1993) Ilmu dan Perubahan Sosial: Suatu Teori Pendidikan. Yogyakarta: Rake Sarasin.

Pohl, F. (2006) 'Islamic Education and Civil Society: Reflections on the Pesantren Tradition in Contemporary Indonesia', Comparative Education Review, 50(3), pp. 389-409.

Qomar, M. (2005) Pesantren: dari transformasi metodologi menuju demokratisasi institusi. Erlangga.

Raharjo, M. D. (1985) Penggul atau Dunia Pesantren. Jakarta: LP3M.

Umar, N. (2000) Ensiklopedia Tematis Ayat al-Quran dan Hadist. Jakarta: Widiya Cahaya.

Wahid, A. (2001) Menggerakan Tradisi, Esai-esai Pesantren. Yogyakarta: LKIS.

https://pasuruankota.bps.go.id/statictable/2018/03/09/1822/jumlahkejahatan-menurut-jenis-kejahatan-dan-kabupaten-kota-di-provinsijawa-timur-tahun-2014-2016.html

https://www.wartabromo.com/2019/12/31/tahun-2019-kasus-narkobadi-wilayah-hukum-polres-pasuruan-kota-terdapat-tren-peningkatan/ 
